\title{
Dzienniki i tygodniki jako źródło badań nad oświatą W poszukiwaniu alternatywnych spojrzeń na szkolnictwo średnie Galicji w dobie autonomii
}

Fenomen szkolnictwa średniego Galicji doby autonomicznej od wielu dziesiątków lat stanowi zagadnienie szeroko eksplorowane przez historyków. Prac poświęconych tej tematyce powstało już tak wiele, że przed każdym nowym badaczem pojawia się skądinąd słuszne pytanie, dotyczące możliwości wniesienia czegoś nowego. Oczywiście wciąż mało wykorzystywane są źródła zgromadzone w archiwach Iwowskich, uważam jednak, że refleksja nad problematyką edukacji galicyjskiej nie powinna ograniczać się jedynie do źródeł - ważna jest metodologia, stosowana w badaniach oświatowych. W ten sposób wciąż aktualne będzie pytanie o sposób wykorzystywania źródeł, namysł nad nimi, a nie tylko zagadnienie samego ich braku lub ograniczoności.

Nawet pobieżna lektura prac poświęconych edukacji w Galicji prowadzi do dość smutnych konstatacji. Zdecydowana większość prezentuje bowiem typowo modernistyczne podejście, skupiając się głównie na takich zagadnieniach, jak programy szkolne, wyposażenia pracowni naukowych, księgozbiory, zestawy mniej lub bardziej wybitnych nauczycieli i uczniów. I pewnie nic w tym złego, gdyż wciąż duża liczba szkół średnich nie posiada nawet podstawowych monografii, kłopot polega jednak na tym, że niewiele ma to wspólnego z nowszymi badaniami kulturowymi, do których zaliczyć przecież trzeba badania nad dziejami oświaty. Co więcej, refleksja nad kierunkiem badań oświatowych, przy jakże dużym ożywieniu metodologicznym, jest bardzo słaba, a więc tym bardziej potrzebna.

Przejawia się to w pytaniach badawczych albo raczej ich ograniczonym zestawie, podejmowanych przez badaczy oświatowych. Przykładowo, poruszając

* Dr, Zakład Historii Oświaty i Kultury, Instytut Historii, Wydział Historyczny, Uniwersytet Jagielloński, ul. Gołębia 13, 31-007 Kraków. 
się wciąż w dość klasycznych ujęciach, w bardzo nielicznych pracach można znaleźć próby odpowiedzi na pytania, w jakim stopniu otoczenie szkolne (konkretne umiejscowienie budynku w danej przestrzeni miejskiej), pieczołowicie wymieniane eksponaty poszczególnych pracowni, czy choćby dane jednostki wpływały na jakość codziennej egzystencji szkolnej. Niewiele da się też powiedzieć o społecznym odbiorze poszczególnych szkół, a próby odpowiedzi na to pytanie zazwyczaj ograniczone są do cytatów z pamiętników i wspomnień byłych uczniów.

Tego typu „bolączki” pojawiające się przy czytaniu artykułów i książek traktujących o szkołach średnich wynikają ze specyficznej podstawy źródłowej, jaką wykorzystują ich autorzy. Rzadko kto przeprowadza obszerną kwerendę prasową, pozwalającą rozszerzyć perspektywę badawczą. Podstawą prac dalej pozostają drukowane sprawozdania szkolne, materiały archiwalne, wspomnienia czy lektura prasy fachowej, dotyczącej szkół - sporadycznie poszerzone o wyrywkowo przeprowadzoną lekturę wybranych tytułów pism lokalnych. A przecież ograniczenie spojrzenia tylko do pewnej specyfiki źródeł powoduje zawężenie perspektywy. Co więcej, szkoła staje się przestrzenią tylko oficjalną, gdzie odzwierciedla się wzorce i normy, charakterystyczne dla danego państwa czy ustroju. Czym więc różnią się poszczególne społeczności szkolne, w klasycznym ujęciu, poza nazwą i umiejscowieniem? Indywidualizacja pojawia się co najwyżej w mniej lub bardziej ciekawych anegdotach byłych uczniów, których spojrzenie ma niby odzwierciedlać wyjątkowość i niepowtarzalność danej szkoły. Ale czy tak jest faktycznie, czy raczej w tych wspomnieniach nie mamy do czynienia z zabiegami pamięci - operowaniem historią w bardzo przemyślany sposób lub nawet jej instrumentalnym traktowaniem? Przecież subiektywność spojrzenia konkretnej garstki osób, które zostawiły wspomnienia jest oczywista. Dlaczego więc iść śladem zdecydowanej mniejszości, skoro większość członków społeczności szkolnej śladów pamięci bycia w niej nie pozostawiła? Co więcej, potrzebę utrwalenia klisz pamięci czasów szkolnych zazwyczaj mają ci z absolwentów, którzy albo czymś szczególnym zasłużyli się w tym czasie, albo wybili się swoją działalnością w życiu późniejszym. Mało mamy śladów pamięci zwykłych, szarych członków społeczności szkolnej. Czy jest szansa na wyjście z impasu ${ }^{1}$

W swoich badaniach nad szkolnictwem próbuję spojrzeć na konkretne szkoły jako mikroprzestrzenie - poligon doświadczalny ścierania się, realizowania, wdrażania wzorców, norm i cech pożądanych z punktu widzenia danego systemu polityczno-społecznego a materią, jaką był niepowtarzalny „zestaw” nauczycieli i uczniów, tworzących dane społeczności szkolne w konkretnym czasie. Próbuję odpowiedzieć na pytania dotyczące recepcji wzorców narzucanych z góry, sytuacji „pogranicza” lekcji, przerwy, szeroko pojętej kultury czasu wolnego, a także reakcji uczniów, ale i nauczycieli na świat „nieustannego kontrolowania się”, bo przecież tak trzeba opisać rzeczywistość szkolną czasów austriackich². Uczniów

1 Swoją propozycję metodologiczno-źródłową spojrzenia na badania nad społecznościami szkolnymi zaproponowałem w tekście: Stan i potrzeby badań nad dziejami I Liceum Ogólnokształcącego im. Juliusza Słowackiego w Przemyślu, „Rocznik Przemyski” 2004, t. 40, z. 4: Historia, s. 65-84.

2 Prac dotyczących badania życia codziennego i/lub mikrohistorii powstało w literaturze polskiej (abstrahując od ustaleń badaczy zagranicznych) bardzo dużo i mogą być one niezmiernie inspirujące dla badaczy dziejów oświaty i wychowania. Zob. np. E. D o m a ń s k a, Mikrohistorie: spotkania 
pilnowali nauczyciele, a poprzez mundur łatwo ukazujący szaremu obywatelowi, z jakiego gimnazjum uczeń pochodzi - także mieszkańcy danych miejscowości. Nauczyciele i dyrektorzy również byli nieustannie śledzeni, „postrzegani”, ograniczani w swej prywatności. Machina szkoły czasów austriackich nie pozwalała na indywidualność, ale zmuszała do nieustannej służby poprzez nieustanną społeczną inwigilację $e^{3}$. Pisze o tym choćby Zygmunt Skorski, dyrektor gimnazjum jaworowskiego, narzekając, że wielu nauczycieli nie dawało sobie rady z presją publicznej kontroli4.

Prasa galicyjska - polska, ukraińska czy niemiecka - niezmiernie interesowała się tematyką szkół średnich ${ }^{5}$. Wszak średnie wykształcenie stanowiło przepustkę do świata urzędów i zaszczytów, a wciąż było udziałem nielicznych. Z kolei posiadanie przez określone miejscowości szkoły średniej, a z czasem odpowiedniej ich liczby podnosiło ich prestiż. Inna rzecz, że nawet w średniej wielkości miastach, jak Przemyśl, Tarnopol, Stanisławów, Tarnów czy Kołomyja, gimnazja i szkoły realne stanowiły „oczko w głowie” miejscowych społeczeństw, a zainteresowanie opinii publicznej tym, co działo się w poszczególnych „zakładach” widać właśnie na przykładzie gazet. Nawet pobieżna lektura prasy prowincjonalnej pozwala uchwycić tę specyfikę.

w międzyświatach, Poznań 1999 [wyd. II uzupełnione i poprawione, 2005]; Historia społeczna, historia codzienności, mikrohistoria, przeł. A. Kopacki, Warszawa 1996; K. P o l a s i k, Antropologiczny rekonesans historyka. Szkice o antropologii historycznej, Bydgoszcz 2007; N. Z. D a v i s, Powrót Martina Guerre'a, przeł. P. S z u I g i t, Poznań 2010. Zob. także E. D o m a ń s k a, Historia antropologiczna. Mikrohistoria, s. 195-234 oraz Wybrane prace na temat historii antropologicznej i mikrohistorii w Polsce, zestawiła E. D o m a ń s k a, s. 235-246].

${ }^{3}$ Zob. T. P u dłocki, Blask szarości... Życie codzienne w I Państwowym Gimnazjum im. Juliusza Słowackiego w Przemyślu w latach 1918-1939, Przemyśl 2004; t e n że, Na droge tam, gdzie włada duch!... Wzorce i ideały II Drużyny Harcerskiej działającej przy Gimnazjum Słowackiego w Przemyślu w latach międzywojennych, „Rocznik Przemyski” 2006, t. 42, z. 4: Historia, s. 187-194; idem, Pomiędzy ideałem a rzeczywistością - życie codzienne uczniów Gimnazjum Morawskiego w Przemyślu w okresie międzywojennym. Wybrane zagadnienia, „Rocznik Przemyski” 2007 t. 43, z. 4 Historia s. 169-178; t e n ż e, Na rozstaju wzorców i pragnień - życie codzienne uczniów I Gimnazjum w Przemyślu na początku XX wieku, mszps złożony do Księgi Pamiątkowej prof. Juliana Dybca [w druku]; t e n ż e, Rola religii w życiu codziennym społeczeństw gimnazjalnych na przykładzie szkół średnich Przemyśla w latach 1867-1939, mpis złożony do druku w wydawnictwie Prykarpackiego Uniwersyetetu im. W. Stefanyka w Iwano-Frankiwsku. W ujęciu szkoły na zasadach relacji władzy bardzo pomocna była dla mnie teoria M. F o u c a u I t a (Nadzorować i karać. Narodziny więzienia, Warszawa 1998).

${ }^{4}$ Z. S k or s k i, Nauczyciel poza szkołą, „Muzeum” 1917, t. 31, s. 349-353.

${ }^{5}$ Podczas pisania tego artykułu swoje wnioskowanie oparłem na lekturze następujących gazet: „Dziennik Przemyski” 1905; „Echo Przemyskie” 1896-1918; „Echo znad Sanu” 1885; „Gazeta Brodzka” 1895; „Gazeta Jarosławska” 1891-1892; „Gazeta Kołomyjska” 1899-1904; „Gazeta Naddniestrzańska” 1884-1889; „Gazeta Przemyska” 1887-1894, 1907-1913; „Gazeta Samborska” 1894, 1905-1913; „Głos Pokucki” 1899; „Głos Polski” 1904-1905; „Głos Przemyski” 1899-1903; „Kurier Drohobycki” 1900; „Kurier Kołomyjski” 1909; „Kurier Lwowski” 1886-1891; „Kurier Przemyski” 18941897, 1906-1907; „Kurier Stryjski” 1895-1904; „Moriah” 1903; „Nowa Reforma” 1882-1914; „Nowy Głos Przemyski” 1903-1939; „Promień” 1899-1904; „Przegląd Przemyski” 1911; „Przemyska Reforma Miejska” 1909; „Psikus” 1902-1903; „Reforma” 1882; „San” 1879; „Słowo Polskie” 1897-1914; „Tydzień. Gazeta Samborsko-Drohubycka” 1909; „Tygodnik Samborsko-Drohobycki” 1900-1904; „Tygodnik Tarnopolski” 1904; „Wieści znad Sanu” 1885. 
Prasa nachylenia konserwatywnego czy klerykalnego stanowiła płaszczyznę nierzadko oficjalnej polityki dyrektorów i nauczycieli (uczniom nie wolno było niczego publikować bez zgody organów szkolnych). Na jej łamach umieszczano ogłoszenia dotyczące wpisów uczniów, egzaminów poprawkowych i maturalnych, w tym imiona i nazwiska absolwentów, a także przewodniczących egzaminów dojrzałości. Co więcej, łatwo na szpaltach prowincjonalnych tygodników znaleźć daty początków i zakończenia lat szkolnych, przerw w zajęciach, przenosin służbowych konkretnych nauczycieli czy też informacje o wizycie ważnych gości, zamykania szkół z powodu epidemii, w tym także nekrologii nawet kiepskich nauczycieli i bardziej wyróżniających się uczniów. Prasa stanowiła zatem przestrzeń reklamy i „urabiania” opinii publicznej, a zatem wpływania na jej osąd i wyrabianie szkole odpowiedniej opinii. Temu służyły nie tak rzadkie artykuły prasowe, pisane przez nauczycieli czy dyrektorów, mające na celu ukazanie czytelnikom pedagogów jako światłych, uczonych, interesujących się wieloma sprawami, a przez to idealnych do sprawowania opieki nad przyszłością narodu, jaką jest młode pokolenie. Niemało wśród nich tekstów nauczycielskich dotyczących pedagogiki, psychologii, czy szeroko pojętego wychowania. Przecież nie wszyscy mieli możliwość publikacji na łamach czasopism fachowych i nie każdy przedarł się ze swoimi tekstami do jakże opiniotwórczych dzienników galicyjskich, jak krakowska „Nowa Reforma” czy Iwowskie „Słowo Polskie”. Na łamach choćby tych największych czasopism codziennych bardzo dużo jest tekstów traktujących o problemach szkolnictwa. Mniej ambitne artykuły ukazywały się na szpaltach tygodników prowincjonalnych. Oczywiście zasięg oddziaływania idei tam głoszonych był bardzo ograniczony, wartość tych tekstów jest jednak inna. Pokazują one recepcję głównych koncepcji psychologiczno-pedagogicznych na prowincji, pozwalają uchwycić metody dydaktyczne stosowane w zwykłych szkołach, a także sporo mówią o mentalności samych autorów, ich światopoglądzie i patrzeniu na świat. Nie wolno wszak zapominać, że większość tych autorów stanowiła elitę umysłową danych ośrodków i choć może nie wybijali się oni poza miejscem zamieszkania, to i tak realizowali dzięki swojej działalności pozaszkolnej szeroko pojętą misję inteligencką.

Tego typu działalność dyrektorów i nauczycieli nie była przypadkowa. Poprzez różne naciski, prywatne kontakty czy też koneksje łatwo można było wpływać na wydawców tygodników prowincjonalnych i wykorzystywać dyskurs publiczny do promowania swojej szkoły (abstrahując od prywatnych ambicji i uzyskania awansu do większego ośrodka, co stanowiło "marzenie” niemal każdego urzędnika galicyjskiego). Widać to choćby na przykładzie prasy większych miejscowości, gdzie redakcje danych tytułów prasowych albo zamieszczały informacje tylko o konkretnej szkole, pomijając inne, albo wychwalały inicjatywy pedagogiczne jednego zakładu, tendencyjnie pisząc o innych. Wszak układy w środowiskach prowincjonalnych były „podstawą egzystencji”, a dyrektorzy szkół średnich, stanowiący trzon miejscowych elit, mogli albo pomóc w sprzedaży gazety, albo jej poważnie zaszkodzić. 
Interesujące wyniki mogą przynieść ogłoszenia prasowe, dotyczące życia członków społeczności szkolnych ${ }^{6}$. Przeważnie są to prośby o przyjęcie na stancje lub wsparcie ubogich uczniów, ale także ogłoszenia o udzielaniu prywatnych lekcji przez danych nauczycieli. Informacje te pozwalają nade wszystko więcej powiedzieć o warunkach życia codziennego i materialnym zapleczu członków społeczności szkolnych, abstrahując od dodatkowych danych biograficznych konkretnych osób.

Podczas analizy informacji prasowych wyłaniają się jednak inne problemy. Poza artykułami programowymi lub ogłoszeniami oficjalnymi pojawiały się w ówczesnej prasie tzw. newsy, dotyczące szeroko pojętego życia szkolnego: recenzje sprawozdań szkolnych, przedstawień teatralnych, opisy wrażeń z wycieczek, z wystaw prac plastycznych czy rękodzieła wyrabianego w szkolnych warsztatach. Newsy obejmują też informacje o charakterze sensacyjnym, które mogą budzić zastrzeżenia, ale czy i temu samemu kryterium nie powinno się poddawać także innych informacji? Zwłaszcza prasa o nastawieniu liberalnym, demokratycznym i socjalistycznym celowała w krytyce „stosunków szkolnych" i w podawaniu ich niekiedy bardzo „smacznych” przykładów. Nawet bardzo pobieżna lektura newsów przynosi zupełnie inny obraz galicyjskiej szkoły średniej. Narzekania na zbyt srogą kwalifikację w jednych szkołach, którym towarzyszą przykłady liberalniejszego traktowania uczniów w innych (przez szereg lat zarzucano to nauczycielom w I gimnazjum polskim w Przemyślu, przeciwstawiając mu podejście nauczycieli z gimnazjum ukraińskiego), przykłady licznych samobójstw uczniowskich nierzadko z powodu nieprzejścia z klasy do klasy, strajki uczniowskie, napady na nauczycieli, uczęszczanie do zakazanych lokali, w tym domów publicznych, złapanie na przeglądaniu pornografii czy na uczestnictwie w wiecach politycznych i szereg innych. Katalog tzw. amoralnych wystąpień uczniowskich powiększa się dzięki dogłębnej lekturze poszczególnych tygodników i pism codziennych, tym samym ukazując czytelnikom zupełnie inny obraz galicyjskiej szkoły.

Również i świat „wzorców męskich” (wszak większość wśród nauczycieli w szkolnictwie średnim przed I wojną światową stanowili mężczyźni), tj. nauczycieli jawi się w innym świetle: kłótnie w gronie nauczycielskim, ambicje zaistnienia w miejscowej przestrzeni publicznej, zapatrywania polityczne i światopoglądowe, wystąpienia antysemickie, działalność patriotyczna, a niekiedy wręcz nacjonalistyczna działalność propagandowa w szkołach, problemy z przełożonymi czy wręcz przykłady kłopotów małżeńskich czy zdrad. Okazuje się zatem, że szeroko rozumiane życie codzienne członków społeczności szkolnej można dość szczegółowo odtworzyć. Co więcej, postulat patrzenia na szkołę „od dołu”, oczami zwykłych ludzi, mieszkańców miast, a więc tym samym „operowanie na krótkim oddechu" można próbować realizować.

${ }^{6}$ Inspirujący metodologicznie może być choćby tekst A. Janiak-Jas iń ska, Ogłoszenia matrymonialne jako źródła wiedzy o obyczajach, [w:] Jak badać obyczaje? Materiały z konferencji zorganizowanej przez Instytut Kultury Polskiej Uniwersytetu Warszawskiego, Łowicz, listopad 2005, Warszawa 2007, s. 60-73. 
Naturalnie pojawia się zastrzeżenie, by nie popaść w przesadę ukazywania szkół jako miejsc nieustannych afer. Niebezpieczeństwo jest tym większe, że prasa prowincjonalna, niekiedy wprost z braku lepszych tematów, zajmowała się powtarzaniem plotek, kalumnii, oszczerstw. Wierzę jednak, że warsztat historyka kultury i oświaty pozwoli na uchwycenie specyfiki danego środowiska i jego niepowtarzalności, a nie doprowadzi na manowce badawcze. Co więcej, dogłębna analiza pozwoli na uchwycenie prawdziwości lub fałszerstwa poszczególnych informacji, a zarazem pokaże zdecydowanie coś więcej - kronikę towarzyską czy sensacyjną miasta, ale nade wszystko mentalność ówczesnych ludzi, na którą nierzadko składały się skłonność do plotkowania i zajmowania się życiem sąsiadów, przy równoczesnym zachowywaniu w życiu oficjalnym wysokiego gorsetu moralnych wartości. Moim zdaniem zatem, zjawisko funkcjonowania wzorców postulowanych i realizowanych stanowi ciekawsze pole badawcze w przestrzeni szkolnictwa i edukacji niż dotychczas podejmowane problemy badawcze, typowe dla klasycznych monografii, a tym samym pozwoli zbliżyć prace z zakresu oświaty do prac antropologicznych? ${ }^{7}$.

Warto zwrócić uwagę na jeszcze jedną kwestię rozszerzenia pola badawczego, które umożliwia dogłębniejsza analiza prasy prowincjonalnej, czyli spojrzenie na szkołę austriacką z punktu widzenia tzw. gender studies. Wszak relacje między płciami i wewnątrz płci to jeden z najważniejszych aspektów polityki scholaryzacji, który świetnie widać na przykładzie galicyjskich szkół średnich. Już sama edukacja i jej rozdział na "męską" i „żeńską" konstruuje takie, a nie inne formy, warunkuje stosunki płciowe i wpływa na ich realizację w sferach prywatnych czy płciowych. Gender jako kategoria analityczna, jak postulowała Joan Wallach Scott, może być w miarę efektywnie badany jako konstruktywny element relacji społecznych, opartych na postrzeganych różnicach między płciami i zarazem sposób oznaczania relacji władzy ${ }^{8}$. Prasa prowincjonalna podaje szereg przykładów na to, w jaki sposób konstruowano męskość wzorców w ramach szkoły - co było w tym systemie wzorców i norm pożądane, a co odrzucane i potępiane9.

A przecież w szkolnictwie średnim żeńskim, gdzie większość nauczycieli w okresie galicyjskim stanowili mężczyźni, problematyka ciała i seksualności jawi się jako jeszcze ciekawsza. Stykają się w tej przestrzeni bowiem dwie płcie: żeń-

7 Zob. m.in.: M. S a h I in s, Z przeprosinami dla Tukidydesa. Rozumienie historii jako kultury i odwrotnie, Kraków 2011; Teoria wiedzy o przeszłości na tle współczesnej humanistyki. Antologia, red. E. Domańska, Poznań 2010; R. T r a b a, Przeszłość w teraźniejszości. Polskie spory o historię na początku XXI wieku, Poznań 2009; E. D o m a ń s k a, Historie niekonwencjonalne. Refleksja o przeszłości w nowej humanistyce, Poznań 2006. Zob. też choćby: F. I n g l i s, Kultura, Warszawa 2007; H. B r a d I e y, Płeć, Warszawa 2008; K. Hausen, Porządek płci. Studia historyczne, Warszawa 2010.

${ }^{8}$ Zob. szerzej: J. W. S c o t t, Gender: A Useful Category of Historical Analysis, [w:] Feminism and History, ed. J. W. Scott, Oxford-New York 1996, p. 152-182. Zob. też: M. G a w i n, Idea wychowania seksualnego dzieci i młodzieży we wczesnym wieku XX w kulturze polskiej (1905-1939), [w:] Jak badać obyczaje..., s. 74-90.

${ }^{9}$ Piszę o tym szerzej w publikacji Iskra świata czy kopcąca pochodnia? Inteligencja w Przemyślu w latach 1867-1939, Kraków 2009, zwłaszcza w podrozdziale Ciało i seksualność, w dużej mierze opartym na analizie relacji wewnątrz szkół średnich Przemyśla (s. 395-409). 
ska - młoda, liczna, którą tworzyły uczennice i męska - starsza, nieliczna, tworzona przez nauczycieli. W epoce, w której pochwalano małżeństwa między niewiele starszym mężczyzną i młodszą kobietą, nie tak rzadko kawalerowie-nauczyciele znajdowali swoje żony wśród uczennic. I tu wyłania się cały zestaw problemów badawczych: techniki flirtu, uników, strategie rozbudzania pożądania, zwracania uwagi i... bycia dostrzeżoną/-ym tylko przez wybranka/-ę, aby nie stać się obiektem zainteresowania całej szkoły. W badaniach nad seksualnością oraz jej przejawami bardzo pomocna jest lektura miejscowej i stołecznej prasy. Dziennikarze miejscowi nierzadko bowiem rejestrowali różnego rodzaju przykłady, mogące pomóc w badaniach nad ciałem, seksualnością, relacjami wewnątrz- i międzypłciowymi, tym samych szerzej ukazując normatywną działalność szkół jako miejsc realizacji konkretnej polityki państwa ${ }^{10}$.

Problemów i pytań badawczych związanych z wykorzystywaniem prasy w badaniach nad oświatą jest o wiele więcej, bynajmniej nie tylko z perspektywy szkolnictwa galicyjskiego. Przełom XIX i XX w. cechuje ogromny rozwój czasopiśmiennictwa, które swoim zasięgiem dociera do masowego odbiorcy - po raz pierwszy w dziejach na taką skalę. Co więcej, nawet małe miejscowości mają ambicję, by posiadać własne tygodniki i tym samym dołączyć do świata postępu. Taka różnorodność i wielość źródeł, szeroko traktujących o sprawach oświatowych, stawia przed badaczami wciąż nowe możliwości poznawcze. Poprzez rozszerzenie perspektywy i bazy źródłowej świat szeroko pojętej szkoły jawi się z zupełnie innej strony, bowiem czy w mikrospołecznościach nie są ważniejsze stosunki międzyludzkie, systemy zachowań, oddziaływań, atmosfera, a więc zindywidualizowane podejście zamiast odtwarzania struktur i form, w ramach których poruszano się? Inna rzecz, że bez struktur i form zjawiska mikrospołeczne nie mogłyby zaistnieć. Dlatego uważam, że wykorzystując dorobek i doświadczenie dotychczasowej historiografii warto - choćby przez dogłębniejszą lekturę prasy prowincjonalnej i liczne korespondencje z prowincji w dziennikach stołecznych poszerzyć spojrzenie na codzienność szkolną, a tym samym z alternatywy historycznej uczynić rzeczywistość i oczywistość.

${ }^{10}$ Zob. m.in. G. M a u t n e r, Analiza gazet, czasopism i innych mediów drukowanych, [w:] Jakościowa analiza dyskursu w naukach społecznych, Warszawa 2011. 